\title{
Efficacy of Pre-emergence Herbicides for the Control of Major Weeds in Maize (Zea mays L.) at Bako, Western Oromia, Ethiopia
}

\author{
Megersa Kebede*, Fufa Anbasa \\ Oromia Agricultural Research Institute, Bako Agricultural Research Center, Bako, West Shoa, Ethiopia \\ Email address: \\ magarsaa430@gmail.com (M. Kebede), fufaanbessa@gmail.com (F. Anbasa) \\ ${ }^{*}$ Corresponding author
}

\section{To cite this article:}

Megersa Kebede, Fufa Anbasa. Efficacy of Pre-emergence Herbicides for the Control of Major Weeds in Maize (Zea mays L.) at Bako, Western Oromia, Ethiopia. American Journal of Agriculture and Forestry. Vol. 5, No. 5, 2017, pp. 173-180. doi: 10.11648/j.ajaf.20170505.15

Received: July 19, 2017; Accepted: August 1, 2017; Published: October 17, 2017

\begin{abstract}
A field experiment was conducted to evaluate efficacy of pre-emergence herbicides against major weeds in maize at Bako during the main rainy season of 2016/17. The trial was laid out in randomized complete block design (RCBD) with three replication, and consisted of five treatments including pre-emergence application of Lunar $537.5 \mathrm{SE}$ at $3 \mathrm{~L} / \mathrm{ha}$, Venus 500 SC at $6 \mathrm{~L} / \mathrm{ha}$ and Prima gram dual Gold 660sc at $3 \mathrm{~L} / \mathrm{ha}$, and two times hand weeding at 25 and 40 DAS and weedy check for comparison. Application treatments boosted maize grain yield over weedy check plots there by reducing weed infestation. Analysis of variance showed statistically significance difference $(\mathrm{P}<0.01)$ for total weed density $\left(\mathrm{m}^{-2}\right)$ and dry weight $\left(\mathrm{gm} .{ }^{-2}\right)$. Significantly the minimum density $\left(8.5 \mathrm{~m}^{-2}\right)$ was observed in plots treated two times hand weeding which was statistically similar with evaluated herbicides. In contrary, the highest $\left(39.1 \mathrm{~m}^{-2}\right)$ was observed in weedy check plots. All the herbicide treatments provided significant control of weeds causing significant reduction in density of target weed flora and also significantly improved the grain yield in comparison with the weedy check. However, no crop injury was observed in any of the herbicide treatments. The maximum grain yield $\left(57.57 \mathrm{qt} \mathrm{ha}^{-1}\right)$ was obtained from Lunar $537.5 \mathrm{SE}$ at $3 \mathrm{~L} / \mathrm{ha}$ followed by two times hand weeding $\left(57.08 \mathrm{qt} \mathrm{ha}^{-1}\right)$ and Venus $500 \mathrm{SC}$ at $6 \mathrm{~L} / \mathrm{ha}\left(54.03 \mathrm{qt} \mathrm{ha}^{-1}\right)$ having the yield advantage of $67.92,67.64$ and 65.82 respectively, whereas; the minimum $\left(18.47 \mathrm{qt} \mathrm{ha}^{-1}\right)$ was from weedy check plots. In general application preemergence herbicides effectively control weeds in maize and reduce yield losses. Thus, the newly tested pre-emergence herbicides (Lunar 537.5 SE at 3L/ha and Venus $500 \mathrm{SC}$ at $6 \mathrm{~L} / \mathrm{ha}$ ) alone could be option to major weeds and increase maize grain yield.
\end{abstract}

Keywords: Efficacy, Maize Yield, Major Weeds, Pre-emergence Herbicides, Residual Action

\section{Introduction}

Maize (Zea mays L.) is one of major cereal grain produced by most small holder farmers in the Sub-Saharan African region and is critical in stimulating economic growth [1]. In Ethiopia, maize can adapt in all regions of the country starting from sea level to 2600 masl in moisture stress lowlands and highlands to lowlands, mid-altitude and highland ecologies receiving adequate amount of rainfall during the growing season Legesse et al. [2]. It is one of the important cereal crops grown in the country. It exceeds all other cereal crops in the country in terms of annual production and productivity [3]. The total annual production and productivity exceed all other cereal crops, though it is suppressed by tef in area coverage Benti et al. [4]. Therefore, considering its importance in terms of wide adaptation, total production and productivity, maize is one of the high priority crops to feed the increasing population of the country Mosisa et al. [5]. Maize is largely consumed as food in various forms. It is also used as animal feed, particularly for poultry. The maize plant which is still green when ears are harvested as baby ears or green ears makes good forage. Generally, the 
principal use of maize is for human consumption in different forms, both home cooked and industrial processed, fermentation and industrial products Farnham et al. [6] and Troyer [7].

In Ethiopia, the national average yields for this crop in 2014 was 3.4 tons per hectare [8], which is far less than the potential yields. The wide gap in yields is due to a wide range of production constraints, which include both biotic and abiotic factors. Among biotic factors, weeds are the major ones. Weed infestation is the basic and major component of low yield in maize crop production system in the country Fasil et al. [9]. Excessive growth of weeds in maize field leads to 25 to $80 \%$ reduction in crop yield or sometimes to a complete crop failure if weeds are left uncontrolled Karlen et al. [10] and Chikoye \& Ekeleme [11]. Weeds compete with crop plants for nutrients, light, space, moisture and many other growth factors through competition and allelopathy, resulting in direct loss to quantity and quality of the produce [12].

Therefore, to enhance maize production and productivity there is a need to look for effective and economically feasible weed management technologies. Weed control practices in maize resulted in 77 to $97 \%$ higher grain yield than weedy check Khan et al. [13]. It can be concluded by Tesfaye et al. [14] that proper control of weeds in maize can increase yield up to $96 \%$. Different weed control methods have been used to manage weeds but mechanical and chemical methods are more frequently used than any other control methods. Cultural methods are still useful but are getting expensive, laborious and time consuming. In less developed countries, the situation still exists where the peak labour requirement is for hand weeding Chikoye et al. [15]. Keeping in view these limitations, the use of herbicides is the best way which gives a quick and cost-effective solution of the numerous weed problems in maize field and hence has gained an important position over conventional methods Ali et al. [16] and Chikoye et al. [17]. Chemical weed control if properly implemented and judiciously utilized is quite effective and efficient method having less harm to the environment concerned also less laborious, low cost and economically feasible Chikoye et al. [18]. Weed control in maize with herbicides have been suggested by many researchers Shakoor et al. [19]; Correa et al. [20] and Owen et al. [21]. Malik et al. [22] reported that herbicides proved effective in controlling weeds and produced relatively more weight of cobs, number of grains $\mathrm{cob}^{-1}, 1000$-grain weight, biological yield and grain yield. In a similar study, Khan et al. [23] reported that chemical weed control as well as hand weeding significantly increased the grain yield of maize.

The usage of pre-emergence herbicides has been advocated as the best option in weeds suspected yields because of their ability to control weeds at initial growth stages of crop and also provide a weed competition free environment to ensure better crop establishment Sharma \& Sandhu [24] and Sunitha et al. [25] in maize. Hassan et al. [26] reported a reduced weed biomass due to use of selective pre-emergence and post emergences herbicides best for controlling different maize weed species. Even though pre-emergence herbicides play a vital role in weed control and weeds are causing drastic yield loss, in Ethiopia, only few pre-emergence herbicides have been introduced and registered against major weeds in maize. Farmers practice cultural methods and used available herbicides repeatedly that has its own backstop. Continuous use of same herbicide for years may create resistance or hardening in weeds plants against that herbicide which reduce herbicide efficacy and the use of alternate herbicides avoids the development of herbicide resistance Owen et al. [27]. Similarly, hand weeding is laborious, time consuming and difficult to practice in large scale farming. For this reason, there is a need to find and evaluate new preemergence herbicides for weed control in maize field at western Oromia, Ethiopia. Having above mentioned points the field experiment was conducted to evaluate the efficacy of different newly introduced pre-emergence herbicides (Lunar 537.5 SE + Venus $500 \mathrm{SC}$ ) with already registered and commonly used herbicide (Primagram Gold 660sc) for the control of major weeds in maize under field condition at Bako, West Shoa, Ethiopia.

\section{Materials and Methods}

\subsection{Description of Study Area}

A field experiment was undertaken during main cropping season of 2016/17 at Bako Agricultural Research Center on station. It is found in the Western part of Ethiopia with about $133 \mathrm{~km}$ from Ambo, the capital town of West Shoa zone and $258 \mathrm{~km}$ from Addis Ababa, the capital city of the country. It is located at $37^{\circ} 02^{\prime}, 739^{\prime}$ E longitude, $09^{\circ} 05^{\prime} 516^{\prime \prime} \mathrm{N}$ latitude and altitude of 1633 m.a.s.l. The soil is sandy in texture. It has a warm-humid climate with annual mean minimum and maximum temperature of $13.6^{\circ} \mathrm{C}$ and $29.1^{\circ} \mathrm{C}$, respectively and receives average annual rainfall of 1264 $\mathrm{mm}$.

\subsection{Experimental Design and Treatments}

The experimental plots were arranged in a random block design, in three replications involving five treatments with an elementary plot size of $6 \mathrm{~m} \times 6 \mathrm{~m}$. The treatments were: preemergence application of Lunar 537.5 SE (3lit ha ${ }^{-1}$ ), Venus 500 SC (6 lit ha ${ }^{-1}$ ) and Primagram dual Gold 660 SC (standard check) (3lit ha ${ }^{-1}$ ), two times hand weeding at 25 and 40 days after sowing (DAS) as farmer's practice and Weedy check (control). Maize variety "BH-546" seed was used as test variety. Two (2) seeds per hill were sown at the spacing of 30 $\mathrm{cm}$ and $75 \mathrm{~cm}$ between plants and rows, respectively and seedlings were thinned out to one plant per hill. NPS and Urea fertilizers were applied at the rate of $100 \mathrm{~kg}$ and $200 \mathrm{~kg} \mathrm{ha}^{-1}$, respectively, where NPS was applied at sowing and Urea was applied in split form $100 \mathrm{~kg}$ at sowing and the rest $50 \%$ was added at knee height (40 DAS). The application of herbicides were commenced at two days after sowing (2 DAS) using Knapsack sprayer fitted with flat fan nozzle by mixing 200 liters of water per hectare. All agronomic practices were kept uniform (as per areas recommendation) for all experimental 
units except test treatments.

Table 1. Description of herbicidal treatments in the experiment.

\begin{tabular}{lllll}
\hline Trade Name & Common Name & Active Ingredients & Application Time $^{\text {Rates Litres ha }^{-1}}$ \\
\hline Venus 500 SC & Atrazine 250 g/l & Atrazine 250 g/L + Ametryn 250 g/L & Pre-emegence & .6 \\
Lunar 537.5 SE & Mesotrione; S-metolachlor; & Mesotrione 125g/lt + S-Metolachlor & Pre-emergence & .3 \\
& Terbuthylazine & $375 \mathrm{~g} / \mathrm{lt}+$ Terbuthylazine 37.5 g/lt & & \multirow{2}{*}{ Primagram dual Gold 660SC } \\
& (s-metolachlor 290 g/l + & S-metolachlor 290g/lt. + Atrazine 370 & Pre-emergence & .3 \\
\hline
\end{tabular}

\subsection{Field Data Collection}

Different data were collected both on maize crop and weed parameters.

\subsubsection{Weed Data Collection}

Data on weed flora found in the experimental field were recorded during the experimentation. Weed infestation was assessed and scored by number and species throwing quadrant of $50 \mathrm{~cm} \times 50 \mathrm{~cm}$ area three times per plot at 75 DAS using method described by Cruz et al. [28]. The counted weeds were separated in to species as broad and grass weed species. Percentage of weed inhibition (PWI) was calculated by the formula of:

$$
\text { Percentage of weed inhibition }(P W I)=\left(N W C-\frac{N W T}{N W C}\right) * 100
$$

Where, NWC \&NWT are number of weeds $\left(\mathrm{m}^{-2}\right)$ in weedy check and any particular treatment, respectively.

The collected weeds were first sun dried and weighted species-wise. The dry weight of each species was taken by an electrical balance and expressed in $\mathrm{gm}^{-2}$. Weed control efficiency (WCE) was calculated using the following formula developed by Sawant and Jadhav [29],

$$
\text { Weed control efficacy }(W C E)=\left(W D C-\frac{W D T}{W D C}\right) * 100
$$

Where, WDC \& WDT are weed dry weight $\left(\mathrm{gm}^{-2}\right)$ in control and any particular treatment, respectively.

\subsubsection{Maize Crop Data Collection}

Different crop data like: plant height $(\mathrm{cm})$, stand count at harvest, field weight $(\mathrm{kg} / \mathrm{plot})$, number of rows per ear, ear length $(\mathrm{cm})$, thousands kernel weight (gm.), moisture content $(\%)$ and biomass $(\mathrm{kg})$ were recorded at different crop growth stage. Data on maize plant height, number rows per ear, earl length $(\mathrm{cm})$ and above ground biomass $(\mathrm{kg})$ were recorded from ten (10) plants selected randomly and tagged from the harvestable rows (net plot) in each plot. Similarly, thousands kernel weight (gm.) and moisture content (\%) were also measured from sampled ears. Stand count and field weight $(\mathrm{kg})$ per plot was made from harvestable rows excluding one row on each side of the plot as to avoid border effect at harvesting. Finally, maize grain yield (qt) per hectare, yield advantage and yield loss was calculated by the formula suggested below.

$$
\text { Adjusted yield }(A Y(k g))=(C W * 0.81) * \frac{(100-A M)}{(100-12.5)}(3)
$$

Where, $\mathrm{CW}$ is $\mathrm{Cob}$ weight and $\mathrm{AM}$ is actual moisture at harvest.

$$
\text { Percentage yield advantage }(P Y A \%)=\frac{Y t-Y C}{Y c} * 100
$$

Where, Yt is yield in any treatment and $\mathrm{Yc}$ is yield in weedy check (control) plot.

Yield loss of the crop due to weed infestation was assessed with the manipulation of the yield obtained from maximum protected plot with yield of lower treatments. Hence, the relative percent grain yield loss (YL) was calculated using formula:

$$
\text { Grain yield loss }(Y L \%)=\left[(Y b t-Y l t) * \frac{100}{Y b t}\right]
$$

Where, Ybt is the yield from maximum protected plot and Ylt is the yield from lower treatments, yields from weedy check.

\subsection{Data Analysis}

The collected data were analyzed using GenStat Statistical package was used for the data analysis and significance test and means were separated using LSD at $p<0.05$. All weed data were transformed before analysis, using the square-root transformation formula $\sqrt{ }(x+0.5)$

\section{Results and Discussion}

\subsection{Weed Infestation}

Different weed flora which comprised of both broad and grass weed species were observed in experimental site. Twelve weed species belonging to five families were appeared to infest the experimental maize crop (Table-2). This result is in agreement with Tesfaye et al. [14] and Mehmeti et al. [30] who found that different weeds species in a single experimental site. Among the total weeds, $66.7 \%$ were broad leaved and $33.3 \%$ were grass weed species. From the major weed flora observed in the experimental plots, Guizotia scarba, Galinsoga parviflora, Stellaria media were among most broad leaf, whereas Eleusina indica, Echinochloa colona were amongst important grass leaf weed species throughout growing season having higher degree of infestation. In contrary, the rest weed species were noticed in lower densities. 
Table 2. Weed flora composition observed in experimental fields at 75 DAS at Bako, 2016/17.

\begin{tabular}{lll}
\hline Scientific Name & Family & Life Form \\
\hline Ageratum conyzoides & Compositae & Annual (Broad leaved) \\
Bidens pachyloma & Compositae & Annual (Broad leaved) \\
Celosia argentea & Amaranthaceae & Annual (Broad leaved) \\
Commelina sps & Commelinaceae & Annual (Broad leaved) \\
Cynodon dactylon & Poaceace & Annual (Grass) \\
Digitaria sps & Poaceace & Annual (Grass) \\
Echinochloa colona & Poaceace & Annual (Grass) \\
Eleusine indica & Poaceace & Annual (Grass) \\
Galinsoga parviflora & Compositae & Annual (Broad leaved) \\
Guizotia scarba & Compositae & Annual (Broad leaved) \\
Nicandra physalodes & Solanaceae & Annual (Broad leaved) \\
Stellaria media & Caryophyllaceae & Annual (Broad leaved) \\
\hline
\end{tabular}

\subsection{Weed Density $\left(m^{-2}\right)$ and Percentages Weed Reduction (\%) at 75 Days after Sowing (75 DAS)}

Results indicated that weed density was influenced by weed control treatments. Analysis of variance depicted that broad leaf, grass leaf and total weed density $\left(\mathrm{m}^{-2}\right)$ were significantly affected $(\mathrm{P}<0.01)$ by different treatments application (Table-3). Significantly the maximum total weed density $\left(39.1 \mathrm{~m}^{-2}\right)$ was observed in weedy check plots, while the minimum $\left(8.5 \mathrm{~m}^{-2}\right)$ was recorded in two times hand weeding which is statistically not different from all used pre-emergence herbicides. The maximum weed density achieved in weedy check plots might be due to lack of any weed management practices which rendered the chance for better weed emergence, growth and development which in turn leads less competition and more time to explore the nutrients from the soil and crop plants by the weeds. Analogous results were reported by Mahadi et al. [31] who noted that a weedy check plots produced the highest weed cover score and dry weight at harvest while herbicides significantly lowered weed density. The minimum weed density observed in two times hand weeding and pre-emergence herbicides treated plots could be due to the sufficient and successful weed control achieved by these practices. The reason for low weeds density in hand weeding plots might be the continuous removal of weeds through manual hoeing and those of pre-emergence herbicides could be attributed to the lowest and late weed germination resulted from effective soil residual activities of herbicides. Khan et al. [32] reported similar result that indicated weed control methods like application of herbicides and hand weeding significantly decreased weed density. Statistically no significance difference was observed among preemergence herbicides regarding to the total weed density. However, numerical difference was noticed. Among those herbicides, plots treated with Lunar 537.5 SE shown a minimum total weed density $\left(9.3 \mathrm{~m}^{-2}\right)$, followed by Primagram $\left(11.8 \mathrm{~m}^{-2}\right)$ and Venus $\left(13.3 \mathrm{~m}^{-2}\right)$.
Table 3. Effects of weed management practices on weed density $\left(m^{-2}\right)$ at 75 days after sowing (75 DAS) at Bako, 2016/17.

\begin{tabular}{llll}
\hline Treatments & Broad leaf & Grass leaf & Total weed \\
\hline Venus & $8.7 \pm 2.9 \mathrm{ab}$ & $4.7 \pm 2.1 \mathrm{~cd}$ & $13.3 \pm 3.6 \mathrm{a}$ \\
Lunar & $8.4 \pm 2.9 \mathrm{ab}$ & $0.9 \pm 0.7 \mathrm{ab}$ & $9.3 \pm 3.0 \mathrm{a}$ \\
Primagram & $11.6 \pm 3.3 \mathrm{~b}$ & $0.2 \pm 0.3 \mathrm{a}$ & $11.8 \pm 3.4 \mathrm{a}$ \\
Hand weeded & $5.6 \pm 2.4 \mathrm{a}$ & $2.9 \pm 1.7 \mathrm{bc}$ & $8.5 \pm 2.9 \mathrm{a}$ \\
Weedy check & $33.1 \pm 5.8 \mathrm{c}$ & $6.0 \pm 2.4 \mathrm{~d}$ & $39.1 \pm 6.3 \mathrm{~b}$ \\
LSD $(0.05)$ & 5.5 & 2.1 & 7.3 \\
CV $(\%)$ & 5.1 & 22.3 & 4.4 \\
F-test & $* *$ & $* *$ & $* *$ \\
\hline
\end{tabular}

Means followed by the same letter within the column are not statistically different at $\mathrm{p}<0.05$ using LSD. The value interpreted in the result is the original data and were square root transformed for variance (CV)

Note: $-* *, *=$ significance difference at $(\mathrm{p}<0.01)$ and $(\mathrm{P}<0.05)$ respectively, $\mathrm{ns}=$ no significance difference, $\mathrm{LSD}=$ List significance difference, $\mathrm{CV}(\%)=$ Coefficient of variation, F-test $=$ Probability value, Venus $=$ Venus $500 \mathrm{SC}$ at $6 \mathrm{~L} / \mathrm{ha}$, Lunar $=$ Lunar $537.5 \mathrm{SE}$ at $3 \mathrm{~L} / \mathrm{ha}$, Primagram $=$ Prima gram dual Gold $660 \mathrm{sc}$ at $3 \mathrm{~L} / \mathrm{ha}$, Hand weeded $=$ Two times hand weeding, Weedy check $=$ un-weeded

All weed management practices were significantly reduced weed density as compared to weedy check plots. However, the levels of reduction vary with experimental treatments based on their nature (Figure-1). Variation in weed density in different treatments was due to varying effect of herbicides and hand weeding. The maximum percentage $(78.26 \%)$ weed reduction was observed for two times hand weeding plots, followed by plots spayed with Lunar $537.5 \mathrm{SE}$ (76.21\%) and primagram dual Gold 660 SC (69.82). The maximum weed reduction observed in plots treated with pre-emergence herbicides provided a good efficacy and appropriate residual activity in controlling the entire spectrum of weeds. These results are in line with those of Muhammad et al. [33] who stated that maximum reduction $(94.03 \%)$ in weed density was recorded in treatment where hand weeding was done.

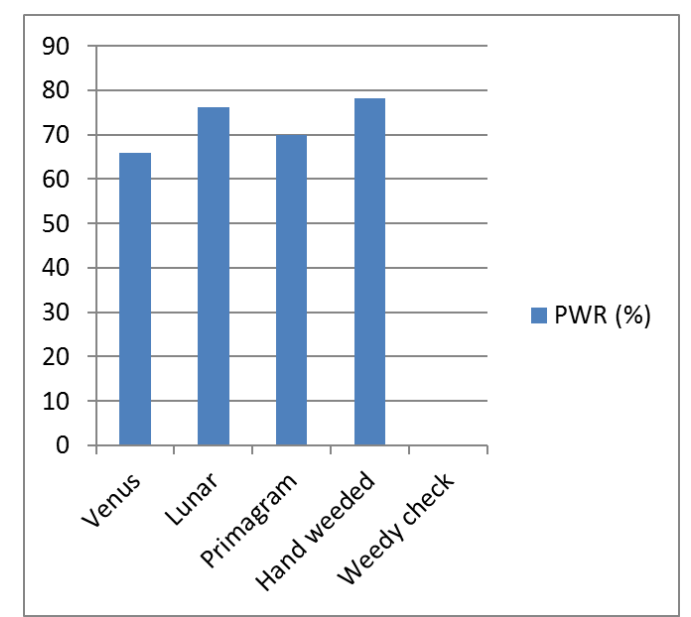

Figure 1. Percentages weed reduction of treatments at 75 days after sowing (75 DAS).

\subsection{Weed Dry Weight $\left(\mathrm{g} \mathrm{m}^{-2}\right)$ and Weed Control Efficacy (\%) at 75 Days after Sowing (75 DAS)}

Results revealed that application of pre-emergence 
herbicides and two times hand weeding were significantly $(\mathrm{P}<0.05)$ decreased weed dry weight $(\mathrm{gm}$.) as compared with weedy check plots (Table-4). There were no significance difference observed among tested pre-emergence herbicides

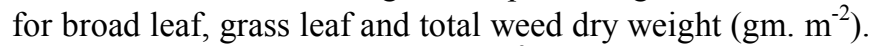
Significantly the lowest $\left(56.7 \mathrm{~g} \mathrm{~m}^{-2}\right)$ total weed dry weight was observed in primagram dual Gold $660 \mathrm{SC}$ treated plots, while the highest $\left(834.0 \mathrm{~g} \mathrm{~m}^{-2}\right)$ was in weedy check. The lowest dry weight achieved from pre-emergence herbicides and two times hand weeding plots could be due to excellent residual effect of herbicides which inhibited weed germination and removal or mechanical injury provided through hand weeding or hoeing to target weed species which in turn reduce density and biomass dry weight. These results are similar to the finding of Abdullah et al. [34] who stated that the minimum dry biomass $\left(33.90 \mathrm{~g} \mathrm{~m}^{-2}\right)$ was recorded in the treatment where pre emergence herbicide Dual gold 960 (S-metolachor) at $1.92 \mathrm{~kg}$ a.i ha ${ }^{-1}$ was applied. Hassan et al. [35] reported a reduced weed biomass due to use of selective pre-emergence and post emergences herbicides best for controlling different maize weed species. The highest weed dry weight achieved from weedy check plots might be due to the maximum weed density or fresh weight achieved by highest resource exploitation by weed plants with high resource competition than maize crop.

Table 4. Effects of weed management practices on weed dry weight $\left(\mathrm{gm}^{-2}\right)$ at 75 days after sowing (75 DAS) at Bako, 2016/17.

\begin{tabular}{llll}
\hline Treatments & Broad leaf & Grass leaf & Total weed \\
\hline Venus & $29.3 \pm 5.2 \mathrm{a}$ & $59.3 \pm 6.9 \mathrm{a}$ & $88.7 \pm 8.9 \mathrm{a}$ \\
Lunar & $40.0 \pm 5.9 \mathrm{a}$ & $57.3 \pm 7.4 \mathrm{a}$ & $97.3 \pm 9.6 \mathrm{a}$ \\
Primagram & $52.0 \pm 6.7 \mathrm{a}$ & $4.7 \pm 1.3 \mathrm{a}$ & $56.7 \pm 6.9 \mathrm{a}$ \\
Hand weeded & $55.7 \pm 6.8 \mathrm{a}$ & $8.7 \pm 2.9 \mathrm{a}$ & $64.4 \pm 7.5 \mathrm{a}$ \\
Weedy check & $672.0 \pm 22.7 \mathrm{~b}$ & $162.0 \pm 11.3 \mathrm{a}$ & $834.0 \pm 26.0 \mathrm{~b}$ \\
LSD $(0.05)$ & 487.1 & 178.1 & 609.7 \\
CV $(\%)$ & 30.8 & 7.2 & 20.3 \\
F-test & $*$ & $n s$ & $*$ \\
\hline
\end{tabular}

Means followed by the same letter within the column are not statistically different at $\mathrm{p}<0.05$ using LSD. The value interpreted in the result is the original data and were square root transformed for variance $(\mathrm{CV})$

Note: $-{ }^{* *}, *=$ significance difference at $(\mathrm{p}<0.01)$ and $(\mathrm{P}<0.05)$ respectively, $\mathrm{ns}=$ no significance difference, LSD $=$ List significance difference, $\mathrm{CV}(\%)=$ Coefficient of variation, F-test $=$ Probability value, Venus $=$ Venus $500 \mathrm{SC}$ at $6 \mathrm{~L} / \mathrm{ha}$, Lunar $=$ Lunar $537.5 \mathrm{SE}$ at $3 \mathrm{~L} / \mathrm{ha}$, Primagram $=$ Prima gram dual Gold $660 \mathrm{sc}$ at $3 \mathrm{~L} / \mathrm{ha}$, Hand weeded $=$ Two times hand weeding, Weedy check $=$ un-weeded

Evaluated herbicides were shown highest weed control efficiency (Figure-2). The highest (93.2\%) weed control efficacy was recorded from Primagram treated plots, closely followed by two times hand weeding, Venus $500 \mathrm{SC}$ and Lunar 537.5 SE having (92.3, 89.4 and 88.3\%), respectively. The higher weed control efficiency with these treatments might be attributed to the lower weed population as well as dry matter accumulation of weeds in these treatments. Higher weed control efficiency recorded under mentioned treatments is also as a result of better control of all types of weeds by herbicides and manual removal of weeds in weed free treatment. These results are in line with the findings of Subhan et al. [36]. They reported that the application of pre emergence herbicide, S-metolachlor at $1843 \mathrm{~g}$ a.i. $\mathrm{ha}^{-1}$ significantly reduced $(90.75 \%)$ the dry weight of weeds. Shah and Koul [37] and Thakur [38] also observed higher WCE under twice hand weeding carried out at 20 and 40 DAS in maize crop.

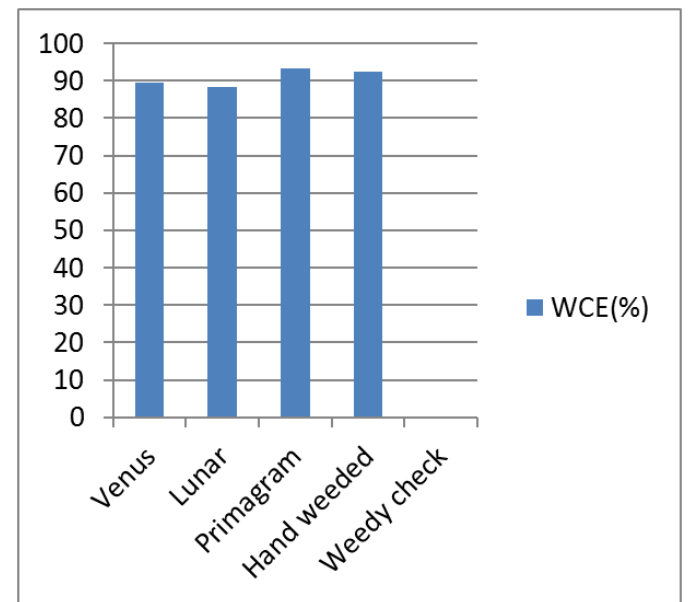

Figure 2. Weed control efficiency (WCE\%) as influenced by weed management practices.

\subsection{Yield Components of Maize as Influenced by Treatments}

Analysed result of data revealed that all weed management treatments boosted yield components of maize over weedy check treatment (Table-5). Increments in yield related parameters might be due to successful weed control and efficiency provided by applied treatments against major weeds. This is in line with the finding of Waheedullah et al. [39] who reported that weed management suppressed the weeds and increased the grain yield and yield components of maize.

The variance analysis regarding to measured yield related parameters like plant height $(\mathrm{cm})$, number of rows per ear and thousands kernel weight (gm.) showed non-significance difference $(\mathrm{P}<0.05)$. However, numerical difference was reflected among tested treatments. Numerically the highest plant height $(291.70 \mathrm{~cm})$ was measured from the plots applied with Lunar 537.5 SE followed by two times hand weeding $(286.30 \mathrm{~cm})$, while the lowest plant height $(277.70$ $\mathrm{cm})$ was obtained from weedy check plots. This lowest plant height might be due to the fact that there was a severe competition of resource between the crop plant and weeds. In the weed control treatments, however, there were sufficient resources for the maize crop plants. Analogous results were reported by Mahadi et al. [31] who showed that some herbicides applied to maize increased the plant height of maize more than the weedy check. Similarly, Pre-emergence application of Lunar 537.5 SE achieved numerically the maximum number of rows per ear (15.47) and thousand kernel weight (400.67 gm.), followed by plots treated with primagram dual Gold $660 \mathrm{SC}$ (15.13) and (400.66 gm.), 
whereas the minimum number of rows per ear (13.90) and thousand kernel weight (350.33 gm.) was obtained from weedy check plots.

Above ground biomass $(\mathrm{kg})$ and ear length $(\mathrm{cm})$ was statistically significantly affected $(\mathrm{P}<0.05)$ by treatments application (Table-5). Pre-emergence herbicides significantly increased above ground biomass as compared with weedy check. Accordingly, significantly the highest above ground biomass $(7.07 \mathrm{~kg})$ was obtained from Lunar 537.5 SE application, followed by pre-emergence application of Primagram dual Gold $660 \mathrm{SC}(5.93 \mathrm{~kg})$. In contrary, the lowest above ground biomass $(2.87 \mathrm{~kg})$ was gained from weedy check plots. Significantly the maximum ear length
$(20.20 \mathrm{~cm})$ was also scored in plots treated with Lunar 537.5 $\mathrm{SE}$, while the minimum $(15.47 \mathrm{~cm})$ was obtained from weedy check plots. The better performance of maize yield related parameters observed in pre-emergence herbicides might be because of the fact that herbicidal application inhibit or suppress the emergence of weeds by providing sufficient soil residual action and shift weed crop competition in favour of crop plants. Similar results were reported by Malik et al. [40] that showed herbicides proved effective in controlling weeds and produced relatively more weight of cobs, number of grains $\mathrm{cob}^{-1}$, 1000-grain weight, biological yield and grain yield.

Table 5. Maize yield related parameters as affected by weed management practices at Bako, 2016/17.

\begin{tabular}{|c|c|c|c|c|c|}
\hline \multirow{2}{*}{ Treatments } & Plant & Ear & Rows & \multirow{2}{*}{ TKW (gm.) } & \multirow{2}{*}{$\frac{\text { A/ground }}{\text { biomass kg }}$} \\
\hline & height $\mathbf{c m}$ ) & length $\mathrm{cm}$ ) & per ear & & \\
\hline Venus & $285.30 \mathrm{a}$ & $19.50 \mathrm{ab}$ & $14.80 \mathrm{a}$ & $390.67 a$ & $5.73 \mathrm{ab}$ \\
\hline Lunar & $291.70 a$ & $20.20 \mathrm{a}$ & $15.47 \mathrm{a}$ & $400.67 a$ & $7.07 \mathrm{a}$ \\
\hline Primagram & $281.80 \mathrm{a}$ & $18.47 \mathrm{ab}$ & $15.13 a$ & $400.67 \mathrm{a}$ & $5.93 \mathrm{ab}$ \\
\hline Hand weeded & $286.30 \mathrm{a}$ & $16.30 \mathrm{ab}$ & $14.60 \mathrm{a}$ & $370.33 a$ & $4.20 \mathrm{bc}$ \\
\hline Weedy check & $277.70 \mathrm{a}$ & $15.47 b$ & $13.90 \mathrm{a}$ & $350.33 a$ & $2.87 \mathrm{c}$ \\
\hline CV (\%) & 13.3 & 7.3 & 10.5 & 12.1 & 6.1 \\
\hline F-test & ns & $*$ & ns & ns & $*$ \\
\hline
\end{tabular}

Means followed by the same letter within the column are not statistically different at $\mathrm{p}<0.05$ using LSD.

Note:- $* *, *=$ significance difference at $(\mathrm{p}<0.01)$ and $(\mathrm{P}<0.05)$ respectively, $\mathrm{ns}=$ no significance difference, $\mathrm{LSD}=\mathrm{List}$ Significance difference, $\mathrm{CV}(\%)=$ Coefficient of variation, F-test = probability value, Venus = Venus $500 \mathrm{SC}$ at $6 \mathrm{~L} / \mathrm{ha}$, Lunar=Lunar $537.5 \mathrm{SE}$ at $3 \mathrm{~L} /$ ha, Primagram $=$ Prima gram dual Gold $660 \mathrm{sc}$ at $3 \mathrm{~L} / \mathrm{ha}$, Hand weeded $=$ Two times hand weeding, Weedy check $=$ un-weeded, Rows per ear $=$ Number of rows per ear, TKW $(\mathrm{gm}$. $)=\mathrm{Thousand}$ kernel weight, A/ground biomass $(\mathrm{kg})=$ Above ground biomass per plot in kilogram

\subsection{Maize Grain Yield and Yield Advantage as Influenced by Treatments}

Result of data revealed that all weed management treatments increased grain yield and yield advantage of maize over weedy check treatment (Table-6). Increased in yield and advantage might be due to successful weed control and efficiency provided by applied treatments against major weeds.

Statistical analysis of the data indicated that application of pre-emergence herbicides and two times hand weeding was significantly $(\mathrm{P}<0.01)$ increased maize grain yield over weedy check plots (Table-6). This result is in conformity with that of Khan et al. [23] those reported chemical weed control as well as hand weeding significantly increased the grain yield of maize. Mean values showed that the highest grain yield $\left(57.57 \mathrm{qt} \mathrm{ha}^{-1}\right)$ was obtained by application of Lunar 537.5 SE (3lit $\mathrm{ha}^{-1}$ ), closely followed by two times hand weeding (57.08 $\mathrm{qt} \mathrm{ha}^{-1}$ ), and while the lowest grain yield (18.47 $\mathrm{qt} \mathrm{h}^{-1}$ ) was produced in weedy check treatment (Table-4). Statistically non-significance difference $(\mathrm{P}<0.05)$ was noticed among practiced treatments except weedy check. Increased in yield in pre-emergence herbicides treated plots could be attributed to the efficient weed control achieved and thus the crop utilized almost all the available resources. The same results were reported by Sharma \& Sandhu, [24]; Sunitha et al. [25] which stated that the usage of pre- emergence herbicides has been advocated as the best option in weeds suspected yields because of their ability to control weeds at initial growth stages of crop and also provide a weed competition free environment to ensure better crop establishment in maize. This result is also in line with Khan et al. [41], Khan et al. [42] and Khan and Hassan [43] those reported excellent weed control and significant yield increases over untreated (control) in corn with herbicides application in maize crop as compared to control. Decrease in grain yield in weedy check (control) treatment could be due to the maximum weed infestation and growth associated with the plots which consumed more resources in favors of crop plants. This is accordance with the findings of Karlen et al. [10] and Chikoye \& Ekeleme [11] who reported that excessive growth of weeds in maize field leads to 25 to $80 \%$ reduction in crop yield or sometimes to a complete crop failure if weeds are left uncontrolled. Marwat and Khan [44] also pointed that increasing in dry weight of the weed decrease the yield of crop.

Pre-emergence application of herbicides and hand weeding achieved the maximum grain yield advantage over weedy check plots (Table-6). Treatments gave yield advantages of Lunar 537.5 SE (67.92), hand weeding (67.64), Venus 500 SC (65.82) and Primagram dual Gold 660 SC (64.60). This could be due to the fact that all treatments provided successful control of major weeds without any side effect to the crop which in turn resulted in highest grain yield i.e. yield 
advantage, where the yield losses $(67.92 \%)$ was scored in weedy check (control) plots. This is in analogy with the results of Khan et al. [13] who stated that Weed control practices in maize resulted in 77 to $97 \%$ higher grain yield than weedy check. It can also be concluded by Tesfaye et al. [14] that proper control of weeds in maize can increase yield up to $96 \%$.

Table 6. Maize grain yield and yield advantages as affected by weed management practices at Bako, 2016/17.

\begin{tabular}{lll}
\hline Treatments & yield ha-1 (qt) & Yd. adv. (\%) \\
\hline Venus & $54.03 \mathrm{a}$ & 65.82 \\
Lunar & $57.57 \mathrm{a}$ & 67.92 \\
Primagram & $52.17 \mathrm{a}$ & 64.60 \\
Hand weeded & $57.08 \mathrm{a}$ & 67.64 \\
Weedy check & $18.47 \mathrm{~b}$ & ---- \\
LSD (0.05) & 10.90 & \\
CV (\%) & 10.9 & \\
F-test & $* *$ & \\
\hline
\end{tabular}

Means followed by the same letter within the column are not statistically different at $\mathrm{p}<0.05$ using LSD.

Note: - **, $*$ significance difference at $(\mathrm{p}<0.01)$ and $(\mathrm{P}<0.05)$ respectively, $\mathrm{ns}=$ no significance difference, $\mathrm{LSD}=$ List Significance difference, $\mathrm{CV}(\%)=$ Coefficient of variation, $\mathrm{F}$-test $=$ probability value Yield ha ${ }^{-1}(\mathrm{qt})=$ Yield per hectare in quintal, Yd adv. $(\%)=$ Percentage yield advantage

\section{Conclusions}

Weeds can pose paramount yield losses on maize crop; hence control of weeds in the fields of maize is very essential for obtaining good crop harvest and reduces losses due to weeds. Chemical weed control is among the effective option in controlling weeds and produced relatively more biological and grain yield. In Ethiopia, few effective pre-emergence herbicides have been verified and introduced for weed management. From above result it could be concluded that, pre-emergence application of Lunar 537.5 SE and Venus 250 alone showed convincing result to control major weeds that infested the maize field. These herbicides could also score significantly increased in the grain yield of maize over the Primagram dual Gold 660 SC (standard check) chemical application of these newly tested pre-emergence herbicides two days after sowing (2 DAS) with 200 litres of water per hectare can be recommended as weed management option in study area and similar agro-ecology in Ethiopia.

\section{Acknowledgements}

The authors would like to present special thanks to the Oromia Agricultural Research Institute (OARI) and Bako Agricultural Research Center (BARC) in financing and providing research facilities for this study.

\section{References}

[1] Adetunji M (2007). Economics of maize storage techniques in Kwara State, Nigeria. Pakistan J. Soc. Sci. 4: 442-450.
[2] Legesse B. W., K. V. Pixley, \& A. M. Botha, 2009. Combining ability and heterotic grouping of highland transition maize inbred lines. Maydica 54: 1-9.

[3] CSA (Central Statistical Agency). 2008. Agricultural Sample Survey of the Federal Democratic Republic of Ethiopia 2004/05. Report on land utilization of private peasant holdings, 'Meher' season. Addis Ababa, Ethiopia.

[4] Benti, T., Kebede, M., Legese W., Mosisa W. and Lata T., 1997. Reflections on the successful achievements of hybrid maize breeding program in Ethiopia. In: Ransom J. K., Palmer A. F. E, Zambezi Z. O., Waddington S. R., Pixley K. V. and Jewell D. C., (eds). Maize productivity gains through research and technology dissemination. pp 67-71.

[5] Mosisa W., J. Abdurehman, L. Tulu, H. Juna, L. Wolde, K. Yihun, W. Abera, A. Guta, S. Tariku, T. Asefa, T. Birhanu, Y. Beyene and H. Zeleke. 2001. Development of improved maize germplasm for the mid and low altitude sub-humid agroecologies of Ethiopia. Proceedings of the second National Maize Workshop of Ethiopia. Addis Ababa, Ethiopia. November 12-16, 2001. Pp 27-30.

[6] Farnham, D. E., Benson, G. O. \& Pearce, R. B. 2003. Corn perspective and culture. Pp. 1-33. In: P. J. White \& L. A. Johnson (eds). Corn: Chemistry and Technology. American Association of Cerial Chemists, St. Paul, Minnesota, USA. ng of highland transition maize inbred lines. Maydica 54: 1-9.

[7] Troyer, A. F. 2004. Background of US hybrid corn II: Breeding, climate and food. Crop Sci., 44: 370-380.

[8] Abate T, Shiferae B, Menkir A, Wegary D, Kebede Y, Tesfaye K, Kassie M, Bogale G, Tadesse B, Keno T. 2015. Factors that transformed maize productivity in Ethiopia. Food security 7 (5): 965-981.

[9] Fassil Reda, Matias Mekuria, Rezene Fessehayie and Tamado Tana, 2006. Weed research in sorghum and maize. Pp. 303323. In: Abraham Tadesse (eds.) proceeding of the $14^{\text {th }}$ annual conference of the plant protection society of Ethiopia (PPSE) 19-22 December 2006, Addis Ababa, Ethiopia.

[10] Karlen, L. D., D. D. Buhler, M. M. Ellusbury, S. S. Andrews, 2002. Soil, weeds and insect management strategies for sustainable agriculture. J. Biol. Sci. 2, 58-62.

[11] Chikoye, D., F. Ekeleme, 2003. Cover crops for cogon grass management and effects on subsequent yield. Weed Sci. 51, 792-797.

[12] Gupta, O. P. 2004. Modern weed management (2 ${ }^{\text {nd }}$ Ed.). Agrobios Jodhpur, India. pp. 18-23.

[13] Khan, SA, N Hussain, IA Khan, M Khan and M Iqbal. 1998. Study on weed control in maize. Sarhad Journal of Agriculture, 14: 581-586.

[14] Tesfaye A, Amin M, Mulugeta N (2014) Management of Weeds in Maize (Zea mays L.) through Various Pre and Post Emergency Herbicides. Adv Crop Sci Tech 2: 151.

[15] Chikoye, D, J Ellis- Jone, C Riches and L Kanyomeka. 2007. Weed management in Africa: Experiences, Challenges and Opportunities. Pp. 652-653. In: $16^{\text {th }}$ International plant Protection Congress.

[16] Ali, R, SK Khali, SM Raza and H Khan. 2003. Effects of herbicides and row spacing on maize (Zeamays L.) Pakistan Journal of Weed Science Research, 9: 171-178. 
[17] Chikoye, D., S. Schulz, F. Ekeleme, 2004. Evaluation of integrated weed management practices for maize in the northern Guinea savanna of Nigeria. Crop Prot. 23, 895-900.

[18] Chikoye D, Udensi UE and Lum AF (2005) Evaluation of a new formulation of atrazine and metolachlor mixture for weed control in maize in Nigeria. Crop Protection 24 (11) 10161020 .

[19] Shakoor, A, M Nadeem and CO Ahmed. 1986. Efficiency of different herbicides for control of weed in maize under rainfed conditions. Pakistan Journal of Agricultural Research, 7: 264-268.

[20] Correa AJA, De La Rosa Mora MM, Dominguez YJA (1990). Demonstration plots for chemical weed control in rain fed maize (Zea mays L.) sown with minimum tillage in Acolmn Mexico Revist Chapingo 15: 164-166.

[21] Owen MDK, Hartzler RG, Lux J (1993). Wooly cup grass (Eriochloaviosa) control in corn (Zea. mays L.) with Chloroacetamide herbicides. Weed Technology 7: 925-929.

[22] Malik, M. A., F. Zahoor, S. H. Abbas and M. Ansar. 2006. Comparative study of different herbicides for control of weeds in rainfed maize (Zea mays L.). WSSP Absts. Weed Sci. Soc. Pak. Pp: 62.

[23] Khan, M. A., K. B. Marwat, G. Hassan and N. Khan. 2002. Impact of weed management on maize (Zea mays L.) planted at night. Pak. J. Weed Sci. Res. 8 (1-2): 57-61.

[24] Sharma, R. K., K. S. Sandhu, 1985. Residual effect of atrazine and simazine applied to odder maize sown on different dates on the succeeding wheat. Indian J. Weed Sci. 17, 29-34.

[25] Sunitha, N., R. P. Maheshwara and S. Malleswari, 2010 Effect of cultural manipulation and weed management practices on weed dynamics and performance of sweet corn (Zea mays L.). Indian J. Weed Sci. 42, $184-188$

[26] Hassan, A. A. A. and M. K. A. Ahmed. 2005. The influence of some herbicides and additional hoeing in maize growth and yield and yield components. Int. J. Agri. Biol. 7 (5): 708-711.

[27] Owen, M. J., M. J. Walsh, R. Llewellyn and S. B. Powles. 2007. Wide-spread occurrence of multiple herbicide resistance in Western Australian annual ryegrass (Lolium riyidum) populations. Aus. J. Agric. Res. 58 (7): 711-718.

[28] Cruz, E. D., Moody, K. and Ramos, M. B. D. 1986. Reducing variability in sampling weeds in transplant aman rice (Oryza sativa L.). Philippines J. Weed Sci. 13: 56-59.

[29] Sawant, A. C. and Jadhav, S. N. 1985. Efficiency of different herbicides for weed control in transplanted rice in Konkan. Indian J. Weed Sci. 17 (3): 35-39.

[30] Mehmeti AA, Demaj I, Demelezi, Rudari H (2012) Effect of Post-Emergence Herbicides on Weeds and Yield of Maize. Pak J Weed Sci Res 18: 2737.

[31] Mahadi MA, Dadari SA, Mahmud M, Babaji BA, Mani H (2007) Effect of some rice based herbicides on yield and yield components of maize. Crop Protection 26, 1601-1605.
[32] Khan MA, Marwat KB, Khan N, Khan IA (2003) Efficacy of different herbicides on the yield and yield components of maize. Asian Journal of plant Sciences 2, 300-304.

[33] Muhammad, N., M. Ashiq, A. Gaffar, A. Sattar, M. Arshad, 2012. Comparative efficacy of new herbicides for weed control in maize (Zea mays L.). Pak. J. Weed Sci. Res. 18, 247-254.

[34] Abdullah, G. Hassan, I. A. Khan, S. A. Khan, H. Ali, 2008. Impact of planting methods and herbicides on weed biomass and some agronomic traits of maize. Pak. J. Weed Sci. Res. 14, 121-130.

[35] Hassan G, Tanveerl S, Khan and NU, Munir M (2010). Integrating cultivars with reduced herbicide Rates for weed management in maize. Pak J Bot 42: 1923-1929.

[36] Subhan, F., N. U. Din, A. Azim, Z. Shah, 2007. Response of maize crop to various herbicides. Pak. J. Weed Sci. Res. 13, 915.

[37] Shah, M. H. and P. K. Koul, (1990). Fertilizer and herbicide compatibility to control weeds in maize under moisture stress conditions. Annals Agric. Res., 11: 21.

[38] Thakur, D. R. (1994). Weed management in intercropping systems based on maize under rain fed mid Hill condition. Indian J. Agron., 39: 203.

[39] Waheedullah, M. A. Khan. S. Arifullah and M. Sadiq. 2008. Evaluation of Integrated weed management practices for maize (Zea mays L.). Pak. J. Weed Sci. Res. 14 (1-2): 19-32.

[40] Malik, M. A., F. Zahoor, S. H. Abbas and M. Ansar. 2006. Comparative study of different herbicides for control of weeds in rainfed maize (Zea mays L.). WSSP Absts. Weed Sci. Soc. Pak., 62p.

[41] Khan, M., N. Haq and A. Q. Syed. 1991. The effect of pre and post-emergence herbicide on weeds control and grain yield of maize. Pak. J. Weed Sci. Res. 4: 118-124.

[42] Khan, M., N. Haq and M. Khan. 1993. The effect of preemergence herbicides on weed control and maize grain yield, on farmers' field. Sarhad J. Agric. 9 (5): 415-421.

[43] Khan, M and W Hassan. 2003. Effect of s-metolachlor on weed control and yield in different crops. Journal of Agriculture, 19: 333-339.

[44] Marwat KB, Khan MA (2007) Climatic variation and growth of Holy Thistle (Silybum marianum Gearth.). Pakistan Journal of Botany 39, 319-327.

[45] Khogali I, Dafalla A, and Hassan A. 2015. Herbicidal Efficacy of atrazine for Weed Control in Maize (Zea mays L.). SUST Journal of Agricultural and Veterinary Sciences, 16 (2): $37-$ 48.

[46] Rasool S, Khan M. 2016. Growth and Yield of Maize (Zea mays L.) as Influenced by Integrated Weed Management under Temperate Conditions of North Western Himalayas. American Journal of Experimental Agriculture. 14 (1): 1-9. 